J. Perinat. Med.

1 (1973) 36

\section{The effects of experimental acute decrease of uterine perfusion and maternal hypoxia on the fetus*}

\author{
D. Berg, J. Schulz, K. Wernicke, R. Muschaweck
}

Department of Obstetrics and Gynecology of the University of Frankfurt am Main (Acting Chairman: Prof. Dr. H. Schmidt-Matthiesen)

Section for Experimental Obstetrics (Head: Prof. Dr. D. Berg)

Received August 23, 1972. Accepted October 1, 1972.
For optimal monitoring of the fetus during birth, cardiotokography is used in modern obstetrics. Clinicians depend upon the recording of cardiac frequency and uterine contractions for therapeutic decisions, in particular when this diagnostic method is complemented by microblood examinations. However, our knowledge about the pathophysiologic interrelations between fetal cardiac frequency patterns, hemodynamics and acid-base metabolism is still quite incomplete.

While clinicians are familiar with the clinical significance of a "silent fluctuation" of the cardiotokography, its cause is unknown, the all-encompassing term "fetal asphyxia" notwithstanding.

Therefore, we have attempted to simulate in our laboratory conditions of fetal distress in acute experiments on the term lamb fetus in order to investigate possible causal interrelations.

Conditions of fetal distress can be caused by a decrease in uterine blood perfusion, e.g. during a contraction or with maternal shock or hypoxia. These conditions must simulate nature as closely as possible for the investigation of the consequences for the fetus of acute maternal-fetal metabolic disturbances. As other investigators, have we used the model of maternal hypoxia in our experiments with some modifications.

\section{Material and methods}

\subsection{Material}

We evaluated the results of 15 experiments on 5 fetal lambs, 7 to 14 days before term. Major difficulties arose with another 3 animals, rendering the results unreliable. Our method for the induction of ovulation and the early diagnosis of pregnancy has been reported elsewhere [24].

\section{Curriculum vitae}

Dietrich Berg, $M$. D., son of a GP, was born in 1935. He began to study Medicine at the Free University of Berlin in 1955, and took bis final exams at Frankfurt University. The title of bis doctoral thesis under Prof. Heller was: "The small ions in mother and child".

In 1968 be got bis diploma as a specialist in obstetrics and gynecology. After joining the staff of Prof. Käser be was appointed university lecturer (Privatdozent) in 1969 on the strength of his paper entitled: "Problems of acid-base status in the perinatal period proper".

\subsection{Surgical preparation}

Following the injection of 0.4 to $0.6 \mathrm{ml}$ pentobarbital ${ }^{1}$ the ewes were intubated and ventilated with a $1: 1 \mathrm{O}_{2} / \mathrm{N}_{2} \mathrm{O}$ mixture and paralyzed with Suxamethonium ${ }^{2}$.

With the animal in the left lateral position, the abdomen was opened with a flank incision. A small rubber catheter was passed around the main branch and, if necessary, around the larger collaterals of the uterine artery of the pregnant uterine horn. Thus the arterial blood flow could be restricted for the ligature experiments. The uterus was then opened in a space free of cotyledons with the fetus remaining in utero. Care was taken that as little as possible amniotic fluid was lost.

\subsection{Measurements}

The arrangement for obtaining data is depicted schematically in fig. 1. Maternal arterial blood

* This work comprises major parts of the doctoral thesis of G. Schwartzkopff

1 Nembutal@, Neodorm@

2 Lysthenon®, Pantolax@ 


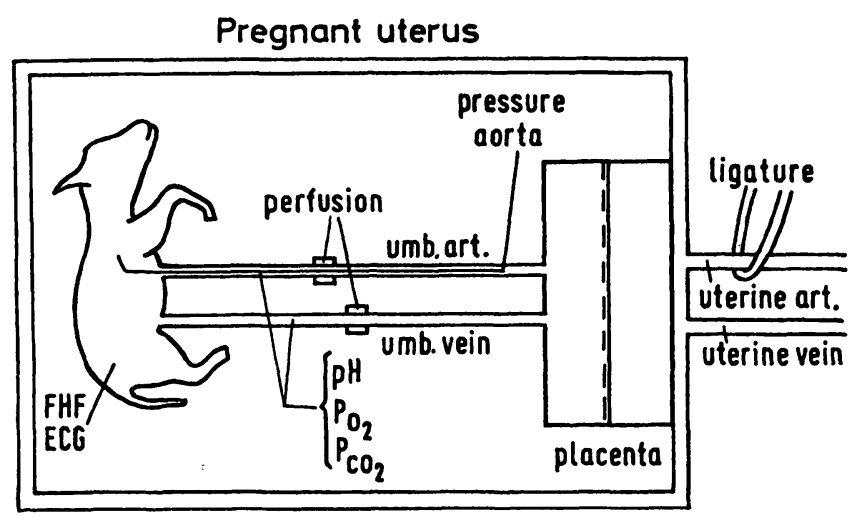

Fig. 1. Experimental design for hypoxia and ligature experiments on term fetal lambs in utero.

was taken from a catheter in the femoral artery. Catheters were introduced into one umbilical artery and into the umbilical vein via small placental vessels. The tip of the arterial catheter was in the fetal abdominal aorta. Electromagnetic STATHAM flow meters were positioned around an umbilical artery and an umbilical vein after removal of adventitia. The fetal ECG was registered from a SALING needle electrode [39] and fed into a Hewlett-Packard cardiotokograph for the computation of beat-to-beat fetal heart rate. The following measurements were obtained:

a) $\mathrm{pH}, \mathbf{P}_{\mathrm{O} 2}, \mathbf{P}_{\mathrm{CO} 2}$ from the maternal femoral artery, the umbilical vein and the fetal abdominal aorta

b) blood flow in each umbilical artery and vein

c) blood pressure in the maternal femoral artery and the fetal abdominal aorta

d) fetal ECG and beat-to-beat heart rate

The cardiovascular data were recorded with a HeLlige six channel writer, the fetal heart rate was recorded on the HEwLETT-PACKARD cardiotokograph.

\subsection{Experimental design}

\subsubsection{Ligature experiments}

Before, during and after restriction of blood flow in the uterine artery by traction at the catheter (fig. 1), blood samples were taken from the fetal vessels for the determination of $\mathbf{p H}, \mathbf{P}_{\mathbf{O}_{2}}$, and $\mathbf{P}_{\mathbf{C O} 2}$. The hemodynamic parameters were recorded throughout. Since the extent of the uterine artery constriction could not be deter- mined quantitatively, the duration of the constriction was not kept constant, but was determined by the fetal measurements.

\subsubsection{Hypoxia experiments}

For the hypoxia experiments we ventilated the ewes with $\mathbf{N}_{2} \mathrm{O}$ alone while keeping ventilation per minute constant. Here, too, the duration and extent of the maternal hypoxia was not kept constant, but was varied according to the fetal response.

\subsection{Calculations and corrections}

In order to correct for the BoHr effect on the $\mathrm{P}_{\mathrm{O} 2}$ value during acidosis we corrected to a $\mathrm{pH}$ of 7.4 with Dils's factor [21]. Values for oxygen saturation were taken from nomogram no. 37 by Thews [48].

\section{Results}

\subsection{Comparability of the results from the two experiments}

We examined whether results from two different experimental designs could be evaluated together. Tab. 1 lists the baseline values for arterial and venous $\mathrm{pH}$ and $\mathbf{P}_{\mathrm{O}_{2}}$. It is seen that there are no significant differences between the fetal

\begin{tabular}{llccc}
\hline & & Ligature & Hypoxia & Total \\
\hline $\mathrm{pH}_{\mathrm{A}}$ & $\mathrm{N}$ & 8 & 7 & 15 \\
& $\overline{\mathrm{X}}$ & 7.24 & 7.22 & 7.23 \\
& $\mathrm{SD}$ & 0.31 & 0.33 & 0.33 \\
\hline $\mathrm{pH}$ & $\mathrm{N}$ & 8 & 5 & 13 \\
& $\overline{\mathrm{X}}$ & 7.33 & 7.21 & 7.28 \\
& $\mathrm{SD}$ & 0.24 & 0.14 & 0.33 \\
\hline $\mathrm{P}_{\mathrm{O}} \mathbf{A}_{\mathrm{A}}$ & $\mathrm{N}$ & 8 & 7 & 15 \\
& $\overline{\mathrm{X}}$ & 16.4 & 15.5 & 16.0 \\
& $\mathrm{SD}$ & 3.9 & 3.2 & 3.6 \\
\hline $\mathrm{P}_{\mathrm{O}} \mathrm{V}$ & $\mathrm{N}$ & $8-$ & 5 & 13 \\
& $\overline{\mathrm{X}}$ & 26.8 & 40.2 & 32.0 \\
& $\mathrm{SD}$ & 3.9 & 15.6 & 12.0 \\
\hline
\end{tabular}

Tab. 1. Baseline biochemical data of the fetus for the ligature and hypoxia experiments. Tabulated are number of measurements $(\mathrm{N})$, mean $(\overline{\mathrm{X}})$ and standard deviation (SD). $\mathrm{pH}_{\mathrm{A}}, \mathrm{pH} \mathrm{V}$ : baseline $\mathrm{pH}$ values before the experiment in the umbilical artery and vein

$\mathrm{P}_{\mathrm{O}_{2}}, \mathrm{P}_{\mathrm{O}_{2}}$ : baseline $\mathrm{PO}_{2}$ values in the umbilical artery 
lambs from the hypoxia experiments and those from the ligature experiments. This is also true for the results in tabs. 2, 3, 4, 5, and 6 . Therefore, we feel justified in considering the results together. An important objection against this treatment of the data could be raised by arguing that the transfer of maternal catecholamines released during the hypoxia experiments into the fetus cannot be excluded. In a single pilot study we examined the transfer of radioactive-labelled adrenalin and noradrenalin from the mother to the fetus (fig. 2). While the presence of radioactive material can be demonstrated in the fetal circulation, it cannot be concluded that this material is biologically active.

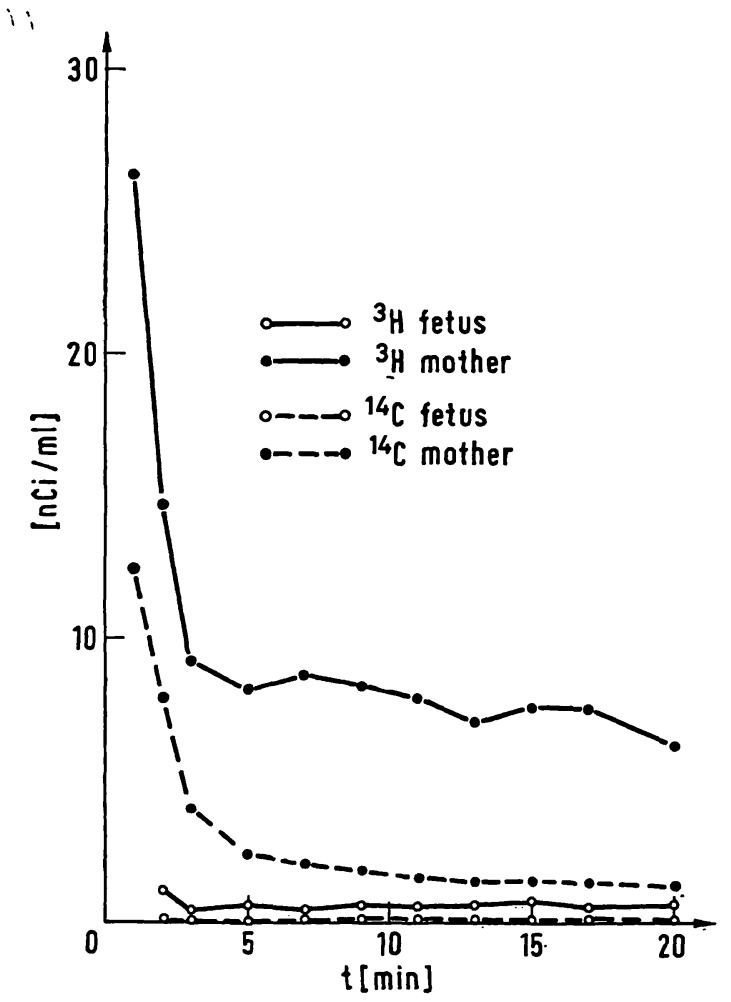

Fig. 2. Transfer of catecholamines from the ewe to the fetal lamb following injection of $0.66 \mu \mathrm{g} \mathrm{D}, \mathrm{L}$-adrenalinecarbinol and $2.5 \mu \mathrm{g}$ norepinephrine within one minute into the maternal jugular vein. Labels: adrenalin: $100 \mu \mathrm{Ci}^{14} \mathrm{C}$, noradrenalin: $200 \mu \mathrm{Ci}^{3} \mathrm{H}$.

\subsection{Biochemical changes}

Tab. 2 demonstrates the change of maternal $\mathbf{p H}, \mathbf{P}_{\mathrm{O}_{2}}, \mathbf{P}_{\mathrm{CO}_{2}}$ and aortic blood pressure before, during and after the experiment.
The mean maternal blood pressure during the ligature experiments rose by $8.75 \pm 6.92 \mathrm{~mm}$ Hg. The difference is statistically highly significant $(p<0.005)$. During the so-called hypoxia experiments the maternal blood pressure rose much more, namely by a mean of $48.57 \pm 18.72 \mathrm{~mm} \mathrm{Hg}$. This difference, too, is highly significant $(p<0.0005)$. The difference of the maternal blood pressure response between the ligature and hypoxia experiments is also highly significant $(\mathrm{p}<0.0005)$. As expected, during the hypoxia experiments fetal $\mathbf{P}_{\mathbf{O}_{2}}$ fell to a varying extent to levels of $12-67 \mathrm{~mm} \mathrm{Hg}$. The changes in $\mathbf{p H}$ and $\mathbf{P}_{\mathrm{CO}_{2}}$ were not significant. In the ligature experiments maternal parameters were not, as a rule, controlled during and after the experiments because major changes were not expected with this experimental design. Because of the position of the animal and the anesthesia, the $\mathrm{P}_{\mathrm{CO} 2}$ of the ewe was generally markedly decreased and the ewes were in respiratory alkalosis.

The fetal changes of the biochemical parameters are summarized in tabs. 3, 4, 5, and 6 . The variation in the baseline $\mathrm{P}_{\mathrm{O} 2}$ and $\mathrm{pH}$ values is noteworthy. Therefore, we have not calculated mean values.

The arterial $\mathbf{P}_{\mathrm{O}_{2}}$ values before the experiment ranged from 11 to $23 \mathrm{~mm} \mathrm{Hg}$ and dropped during the experiment to between 6 and $17 \mathrm{~mm} \mathrm{Hg}$. Depending on the time of the blood sampling, more extensive individual differences were found. A paired t-test on the $\mathrm{P}_{\mathrm{O} 2}$ values demonstrates the significance ( $p<0.0025$ to 0.025 ), with a higher significance being present the earlier the blood sample was obtained.

Different responses were found in the fetal pH values (tab. 3). The baseline values fluctuated between 6.91 and 7.43 for arterial samples and 6.99 and 7.35 for venous. The paired t-test here shows a significant decrease of the $\mathrm{pH}$ value in the arterial blood after only 3-4 minutes $(p<0.025)$. In contrast, the decrease in umbilical venous $\mathbf{p H}$ already occurs after $-0-1$ minute $(p<0.025)$. With increasing time intervals from the beginning of the experiment, the $\mathrm{pH}$ in the umbilical arterial and venous blood increases from 0.02 to 0.03 to $0.09 \mathrm{pH}$ units. The response of the fetal $\mathrm{P}_{\mathrm{CO} 2}$ 


\begin{tabular}{|c|c|c|c|c|c|c|c|c|c|c|c|c|}
\hline $\begin{array}{c}\text { Exper. } \\
\text { No. }\end{array}$ & Contr. & $\begin{array}{c}\mathrm{pH} \\
\text { during }\end{array}$ & after & Contr. & $\begin{array}{c}\mathrm{PO}_{2} \\
\text { during }\end{array}$ & after & Contr. & $\begin{array}{l}\mathrm{PCO}_{2} \\
\text { during }\end{array}$ & after & Contr. & $\begin{array}{l}\text { PAorta } \\
\text { during }\end{array}$ & after \\
\hline$H 1$ & 7.69 & 7.61 & 7.56 & 186 & 29 & 103 & 31 & 21 & 25 & 67 & 99 & 69 \\
\hline 2 & 7.47 & 7.62 & 7.62 & 84.5 & 59 & 65 & 31.5 & 18 & 30 & 82 & 100 & 85 \\
\hline 3 & 7.60 & 7.56 & 7.58 & 92 & 40 & 92 & 28 & 24 & 25 & 68 & 111 & 66 \\
\hline 4 & 7.63 & 7.72 & 7.66 & 78 & 23 & 59.5 & 28 & 22 & 19 & 111 & 163 & 115 \\
\hline 5 & 7.72 & 7.78 & 7.66 & 68 & 15.5 & 110 & 21 & 19.5 & 15 & 96 & 160 & 92 \\
\hline 6 & 7.34 & 7.65 & 7.54 & 90 & 67 & 68 & - & - & - & 81 & 142 & 87 \\
\hline 7 & 7.58 & - & - & 68 & 12 & 72 & 37 & 79 & 55 & 83 & 153 & 92 \\
\hline L 1 & 7.65 & - & 7.62 & 204 & - & 210 & 21 & - & 21 & 71 & 73 & 72 \\
\hline 2 & 7.64 & - & - & 196 & - & - & 28 & - & - & 66 & 71 & 67 \\
\hline 3 & 7.63 & - & - & 111 & - & - & 16.5 & - & - & 72 & 77 & 71 \\
\hline 4 & 7.35 & - & 7.41 & 53 & - & 62.5 & 42 & - & 37 & 128 & 128 & 128 \\
\hline 5 & 7.69 & - & 7.70 & 101 & - & 112 & 26.5 & - & 15.5 & 122 & 137 & 123 \\
\hline 6 & 7.74 & - & - & 68.5 & - & - & 22 & - & - & 108 & 121 & 107 \\
\hline 7 & 7.66 & - & 7.69 & 110 & - & 95 & 15 & - & 14 & 96 & 116 & 96 \\
\hline 8 & 7.20 & - & 7.44 & 58 & - & 74.5 & 27.5 & - & 25.5 & 73 & 83 & 74 \\
\hline
\end{tabular}

Tab. 2. Data from ewes with maternal hypoxia (experiments $\mathrm{H} 1-\mathrm{H} 7$ ) and with ligature of the umbilical artery (experiments L1-L8).

Control: Measurement immediately before experiment

during: Measurement during hypoxia or ligature

after: Measurement after the experiment

$\mathrm{P}_{\text {Aorta: }}$ : Maternal aortic blood pressure in $\mathrm{mm} \mathrm{Hg}$.

During the ligature experiments, the maternal data were recorded less often because major changes were not expected. However, the rise in maternal blood pressure is significant in this experimental design.

\begin{tabular}{|c|c|c|c|c|c|c|c|c|}
\hline \multirow{3}{*}{$\begin{array}{c}\text { Exper. } \\
\text { No. }\end{array}$} & \multicolumn{4}{|c|}{ pHua } & \multicolumn{4}{|c|}{$\mathrm{pHuv}$} \\
\hline & \multirow[t]{2}{*}{ before } & \multirow[t]{2}{*}{ during } & \multicolumn{2}{|c|}{ after } & \multirow[t]{2}{*}{ before } & \multirow[t]{2}{*}{ during } & \multicolumn{2}{|c|}{ after } \\
\hline & & & $0-1 \mathrm{~min}$ & $3-4 \mathrm{~min}$ & & & $0-1 \mathrm{~min}$ & $3-4 \mathrm{~min}$ \\
\hline $\mathrm{H1}$ & 7.43 & 7.34 & 7.29 & 7.30 & 7.47 & 7.41 & 7.34 & 7.32 \\
\hline 2 & 7.09 & 7.08 & 7.13 & 7.07 & 7.08 & 7.12 & 7.11 & 7.08 \\
\hline 3 & 7.15 & 7.21 & 7.21 & 7.18 & 6.99 & 7.02 & 7.00 & 7.01 \\
\hline 4 & 7.25 & 7.35 & 7.22 & 7.16 & 7.28 & 7.41 & 7.24 & 7.23 \\
\hline 5 & 7.28 & 7.06 & 7.04 & 6.91 & 7.23 & 7.15 & 7.10 & 6.99 \\
\hline 6 & 7.16 & 7.25 & 7.23 & 7.30 & - & - & - & - \\
\hline 7 & 7.23 & 7.12 & 7.20 & 7.15 & - & - & - & - \\
\hline L1 & 7.43 & - & 7.44 & 7.41 & 7.48 & - & 7.48 & 7.50 \\
\hline 2 & 7.41 & - & 7.36 & 7.43 & 7.53 & - & 7.46 & 7.47 \\
\hline 3 & 7.28 & - & 7.45 & - & 7.43 & - & 7.45 & - \\
\hline 4 & 7.10 & 7.14 & - & 6.87 & 7.25 & 7.04 & - & 7.05 \\
\hline 5 & 7.28 & 7.17 & 7.07 & 7.15 & 7.24 & 7.21 & 7.14 & 7.13 \\
\hline 6 & 7.31 & 7.37 & 7.24 & 7.35 & 7.41 & 7.41 & 7.38 & 7.37 \\
\hline 7 & 6.91 & - & - & 6.79 & 6.99 & - & - & 6.85 \\
\hline 8 & 7.14 & 7.14 & - & 6.78 & 7,02 & 7.02 & - & 6.86 \\
\hline
\end{tabular}

Tab. 3. Change of the pH value in the umbilical artery and vein with maternal hypoxia (experiments $\mathrm{H} 1-\mathrm{H} 7$ ) and with ligature of the uterine artery (experiments L1-L8). Tabulated are the measurements before, during, and several minutes after the experiment. 


\begin{tabular}{|c|c|c|c|c|c|c|c|c|}
\hline \multirow{2}{*}{$\begin{array}{l}\text { Exper. } \\
\text { No. }\end{array}$} & \multirow[t]{2}{*}{ before } & \multirow[t]{2}{*}{$\begin{array}{l}\mathrm{PCO}_{2} \mathrm{UA} \\
\text { during }\end{array}$} & \multicolumn{2}{|c|}{ after } & \multirow[t]{2}{*}{ before } & \multirow[t]{2}{*}{$\underset{\text { during }}{\mathrm{PCO}_{2} \mathrm{UV}}$} & \multirow{2}{*}{$\begin{array}{r}\text { after } \\
0-1 \mathrm{~min}\end{array}$} & \multirow[b]{2}{*}{$3-4 \mathrm{~min}$} \\
\hline & & & $0-1 \mathrm{~min}$ & $3-4 \mathrm{~min}$ & & & & \\
\hline $\mathrm{H} 1$ & 37 & 35 & 49.5 & 41 & 34 & 30.5 & 40.5 & 28 \\
\hline 2 & 35.5 & 30 & 45 & 32.5 & 26 & 25 & 24 & 21 \\
\hline 3 & 46.5 & 41 & 33 & 49 & 22 & 23 & 31 & 20 \\
\hline 4 & 39 & 34 & 39 & 43 & 32 & 25.5 & 28 & 24 \\
\hline 5 & 35.5 & 37 & 39 & 50 & 27 & 21.5 & 28 & 31.5 \\
\hline 7 & 46 & - & - & - & - & - & - & - \\
\hline L1 & 40 & - & 44.5 & 38 & 35 & - & 39 & 30 \\
\hline 2 & 38 & - & 43 & 37 & 33 & - & 35 & 34 \\
\hline 3 & 22 & - & 40.5 & - & 19 & - & 34 & - \\
\hline 4 & 60 & 61 & - & 54 & 50.5 & 61 & - & 58 \\
\hline 5 & 35.5 & 36 & .35 .5 & 31 & 32.5 & 34 & 26 & 26 \\
\hline 6 & 40.5 & 39 & 49 & 34.5 & 32 & 38 & 34.5 & 28.5 \\
\hline 7 & 50 & - & - & 45 & 38 & - & - & 26 \\
\hline '8 & 61 & 60.5 & - & 90 & 55 & 51 & - & 53 \\
\hline
\end{tabular}

Tab. 4. Changes of $\mathbf{P C O}_{2}$ in the umbilical artery and vein with maternal hypoxia (experiments $\mathrm{H} 1-\mathrm{H} 7$ ) and with ligature of the uterine artery (experiments $\mathrm{L} 1-\mathrm{L} 8$ ). Tabulated are measurements before, during, and several minutes after the experiment.

\begin{tabular}{|c|c|c|c|c|c|c|c|c|}
\hline \multirow{3}{*}{$\begin{array}{l}\text { Exper. } \\
\text { No. }\end{array}$} & \multicolumn{4}{|c|}{$\mathrm{P}_{\mathrm{O}_{2}} \mathrm{UA}$} & \multicolumn{4}{|c|}{$\mathrm{PO}_{2} \mathrm{UV}$} \\
\hline & \multirow[t]{2}{*}{ before } & \multirow[t]{2}{*}{ during } & \multicolumn{2}{|c|}{ after } & \multirow[t]{2}{*}{ before } & \multirow[t]{2}{*}{ during } & \multicolumn{2}{|c|}{ after } \\
\hline & & & $0-1 \mathrm{~min}$ & $3-4 \mathrm{~min}$ & & & $0-1 \mathrm{~min}$ & $3-4 \min$ \\
\hline $\mathrm{H} 1$ & 16 & 16 & 16 & 18 & 30 & 16 & 32 & 25 \\
\hline 2 & 21.5 & 10 & 13 & 32 & 38 & 41 & 30 & 43 \\
\hline 3 & 14.5 & 12.5 & 10 & 16 & 46 & 43 & 21 & 44 \\
\hline 4 & 18 & 10.5 & 9.5 & 16 & 24.5 & 17 & 15 & 30 \\
\hline 5 & 14.5 & 7 & 10 & 18 & 32.5 & 25 & 12.5 & 34 \\
\hline 6 & 12 & 10 & 8 & 12 & - & - & - & - \\
\hline 7 & 11.8 & 13 & 10 & 15 & - & - & - & - \\
\hline L1 & 23 & - & 6 & 19 & 27 & - & 18 & 34 \\
\hline 2 & 11 & - & 17 & 16 & 27 & - & 27 & 30 \\
\hline 3 & 13 & - & 11.5 & - & 21.5 & - & 17 & - \\
\hline 4 & 20 & 12.5 & - & 23 & 26.5 & 28 & - & 31 \\
\hline 5 & 19 & 10 & 17 & 12.5 & 28 & 11.5 & 10 & 11 \\
\hline 6 & 13.5 & 8 & 13 & 14 & 21 & 8 & 29 & 25 \\
\hline 7 & 18 & - & - & 25 & 34 & - & - & 46 \\
\hline 8 & 14 & 12.5 & - & 11 & 29.5 & 27.5 & - & 32 \\
\hline
\end{tabular}

Tab. 5. Changes of partial pressure of oxygen $\left(\mathrm{Po}_{2}\right)$ in the umbilical artery and vein with maternal hypoxia (experiments $\mathrm{H} 1-\mathrm{H} 7$ ) and with ligature of the uterine artery (experiments L1-L8). Tabulated are measurements before, during, and several minutes after the experiment. 


\begin{tabular}{|c|c|c|c|c|c|c|c|c|}
\hline \multirow{3}{*}{$\begin{array}{l}\text { Exper. } \\
\text { No. }\end{array}$} & \multicolumn{4}{|c|}{$\mathrm{S}_{2} \mathrm{UA}$} & \multicolumn{4}{|c|}{$\mathrm{S}_{2} \mathrm{UV}$} \\
\hline & \multirow[t]{2}{*}{ before } & \multirow[t]{2}{*}{ during } & \multicolumn{2}{|c|}{ after } & \multirow[t]{2}{*}{ before } & \multirow[t]{2}{*}{ during } & \multicolumn{2}{|c|}{ after } \\
\hline & & & $0-1 \mathrm{~min}$ & $3-4 \mathrm{~min}$ & & & $0-1 \mathrm{~min}$ & $3-4 \min$ \\
\hline $\mathrm{H} 1$ & 42 & 36 & 30 & 37 & 78 & 37 & 74 & 58 \\
\hline 2 & 36 & 10 & 17 & 56 & 67 & 74 & 54 & 74 \\
\hline 3 & 22 & 20 & 13 & 26 & 71 & 70 & 29 & 70 \\
\hline 4 & 36 & 20 & 12 & 25 & 53 & 42 & 26 & 64 \\
\hline 5 & 26 & 8 & 9 & 21 & 67 & 45 & 16 & 53 \\
\hline 6 & 16 & 14 & 9 & 21 & - & - & - & - \\
\hline 7 & 17 & 17 & 12 & 23 & - & 一 & - & - \\
\hline L1 & 62 & - & 9 & 47 & 72 & - & 47 & 85 \\
\hline 2 & 22 & - & 40 & 40 & 75 & - & 71 & 79 \\
\hline 3 & 22 & - & 25 & - & 55 & - & 43 & - \\
\hline 4 & 32 & 17 & - & 28 & 55 & 46 & - & 52 \\
\hline 5 & 40 & 13 & 26 & 17 & 58 & 17 & 12 & 13 \\
\hline 6 & 27 & 13 & 22 & 28 & 52 & 13 & 13 & 58 \\
\hline 7 & 21 & - & - & 27 & 53 & - & - & 64 \\
\hline 8 & 21 & 17 & - & 8 & 48 & 45 & - & 43 \\
\hline
\end{tabular}

Tab. 6. Changes in oxygen saturation $\left(\mathrm{S}_{2}\right)$ in the umbilical artery and vein with maternal hypoxia (experiments H1 - H7) and with ligature of the uterine artery (experiments L1-L8). Tabulated are values before, during, and several minutes after the experiment.

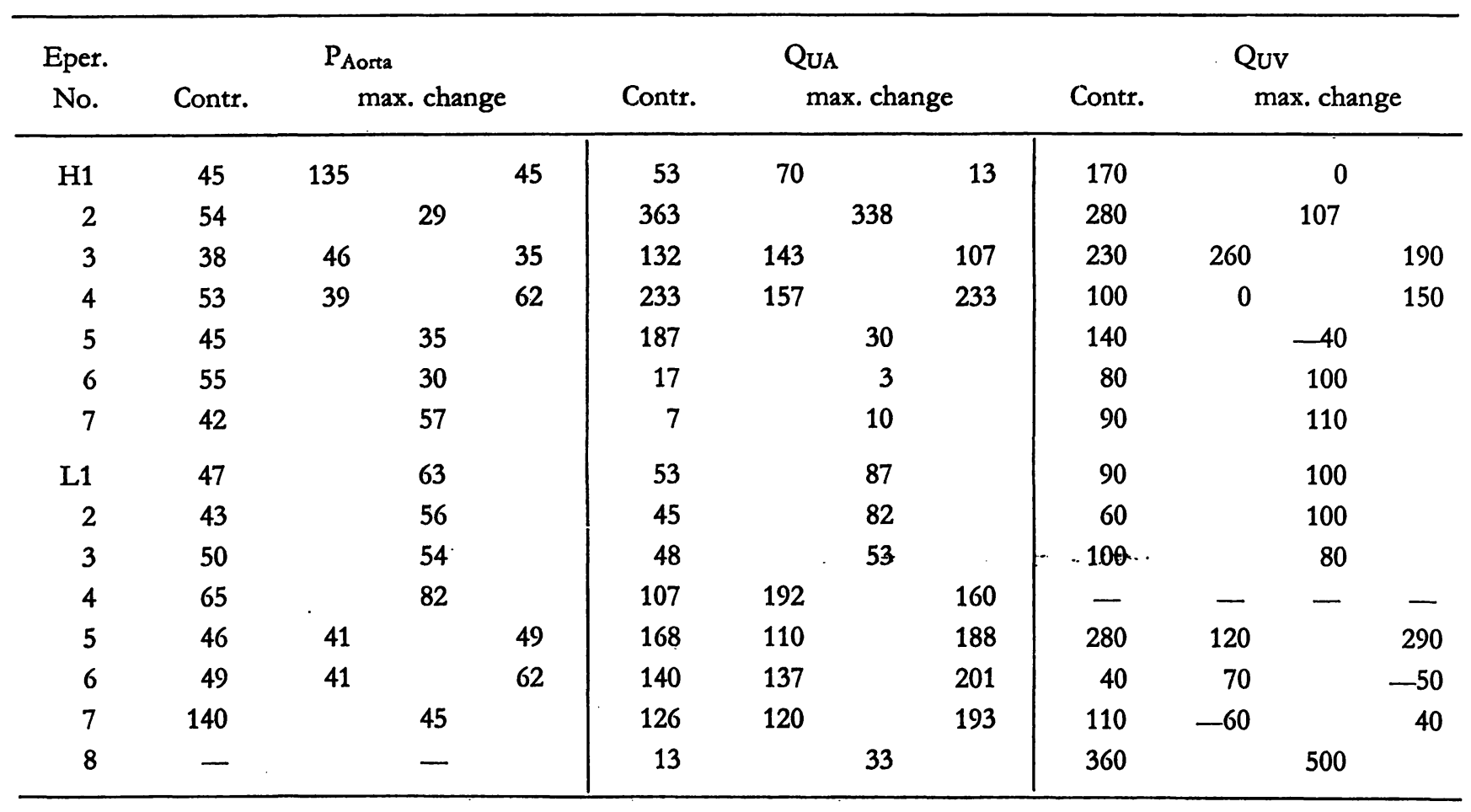

Tab. 7. Changes in fetal aortic blood pressure $\left(\mathrm{P}_{\text {Aorta }}\right)$ in $\mathrm{mm} \mathrm{Hg}$ and the blood flow in one umbilical artery and vein each (QUA and QUv) in $\mathrm{ml} / \mathrm{min}$ with maternal hypoxia (experiments $\mathrm{H1}-\mathrm{H} 7$ ) and with ligature of the uterine artery (experiments $\mathrm{L} 1-\mathrm{L} 8$ ). Tabulated are the measurements before the experiment (Contr.) and the maximum change. 
(tab. 4) was irregularly variable and therefore could not be evaluated.

\subsection{Hemodynamic changes}

Fetal hemodynamic changes are summarized in tabs. 7 and 8 . In several instances the base value changed in only one direction, in other instances in either direction. The maximal changes were used in the table. From tab. 7 it is remarkable that with one exception the fetal aortic pressures were in the normal range between 38 and 65 mm Hg. By contrast, our results for umbilical blood flow showed extreme variations. In three instances the value from the umbilical vein was negative, i. e. the flow was reversed from the fetus to the placenta.

Fetal cardiac frequency before the experiment (tab. 8) was between 115 and 224 beats. In three cases it rose after the beginning of the experi-

\begin{tabular}{|c|c|c|c|c|c|c|}
\hline \multirow{2}{*}{$\begin{array}{l}\text { Exper. } \\
\text { No. }\end{array}$} & \multicolumn{2}{|c|}{ before } & \multicolumn{2}{|c|}{ during } & \multicolumn{2}{|c|}{ after } \\
\hline & $f$ & pattern & $f$ & pattern & $f$ & pattern \\
\hline $\mathrm{H} 1$ & 116 & silent & 13284 & silent & 180 & undulat. \\
\hline 2 & 117 & undulat. & 57 & silent & 122 & undulat. \\
\hline 3 & 150 & saltat. & 80 & silent & 132 & undula \\
\hline 4 & 150 & undulat. & 90 & silent & 148 & undulat. \\
\hline 5 & 115 & $\begin{array}{l}\text { undulat. } \\
\text { saltat. }\end{array}$ & 60 & silent & 158 & undulat. \\
\hline 6 & 152 & undulat. & 65 & undulat. & 127 & saltat. \\
\hline 7 & 145 & undulat. & 65 & $\begin{array}{l}\text { undulat. } \\
\text { saltat. }\end{array}$ & 140 & saltat. \\
\hline L1 & 138 & silent & 14383 & undulat. & 138 & silent \\
\hline 2 & 120 & silent & 13090 & $\begin{array}{l}\text { undulat. } \\
\text { saltat. }\end{array}$ & 145 & silent \\
\hline 3 & 155 & undulat. & 82 & undulat. & 142 & undulat. \\
\hline 4 & 224 & undulat. & 125 & undulat. & 230 & undulat. \\
\hline 5 & 160 & silent & 95 & undulat. & 140 & undulat. \\
\hline 6 & 152 & undulat. & 93 & silent & 158 & $\begin{array}{l}\text { undulat. } \\
\text { saltat. }\end{array}$ \\
\hline 7 & 155 & saltat. & 85 & saltat. & 140 & saltat. \\
\hline 8 & 120 & undulat. & 105 & undulat. & 120 & undulat. \\
\hline
\end{tabular}

Tab. .8. Cardiac frequency pattern and deceleration type with maternal hypoxia (experiments $\mathrm{H} 1-\mathrm{H} 7$ ) and with ligature of the uterine artery (experiments L1-L8). Tabulated are findings before, during, and after the experiment.

$\mathrm{f}$ : frequency in beats/minute pattern: oscillation type according to HAMMACHER. ment and then fell. In all other cases the heart rate decelerated immediately. As a rule, there was an overcompensating tachycardia after the experiment. The base frequency showed all oscillation types described by HAMMACHER [25] including sinusoid curves [7].

\subsection{Correlation between biochemical and hemodynamic changes}

We have attempted to correlate the biochemical and hemodynamic changes found with our experimental design (tab. 9). Among many observations only two were found to be particularly worth mentioning. We were unable to determine any consistent patterns in changes of the oscillation types of the fetal heart rate. No new knowledge was gained when the acceleration and deceleration patterns of cardiac frequency were divided into 7 different types.

An interesting observation is depicted in fig. 3. If the responses in cardiac frequency are divided into those beginning with an initial acceleration and those responding with an immediate deceleration, it is found that there is at least graphically, a marked correlation between the initial $\mathrm{pH}$

\begin{tabular}{|c|c|c|c|}
\hline $\begin{array}{c}\text { Exper. } \\
\text { No. }\end{array}$ & $\underset{\mathrm{pH}_{\mathrm{A}}}{\Delta}$ & $\underset{\mathrm{FHF}}{\Delta}$ & $\begin{array}{c}\Delta \\
\mathrm{PO}_{2} \mathrm{~A}\end{array}$ \\
\hline L 1 & 0.13 & 32 & 0 \\
\hline 2 & 0.02 & 60 & 11.5 \\
\hline 3 & -0.03 & 70 & 2 \\
\hline 4 & 0.09 & 60 & 7.5 \\
\hline 5 & 0.37 & 55 & 7.5 \\
\hline 6 & -0.14 & 87 & 4 \\
\hline 7 & 0.11 & 80 & 1.8 \\
\hline 8 & 0.02 & 55 & 17 \\
\hline H 1 & 0.05 & 30 & -6 \\
\hline 2 & -0.17 & 73 & 1.5 \\
\hline 3 & 0.23 & 99 & 7.5 \\
\hline 4 & 0.13 & 65 & 9 \\
\hline 5 & 0.07 & 59 & 5.5 \\
\hline 6 & 0.12 & 70 & - \\
\hline 7 & 0.36 & 15 & 1.5 \\
\hline
\end{tabular}

Tab. 9. Correlation between biochemical and hemodynamic parameters during hypoxia and ligature experiments. Tabuleted are changes from baseline values for $\mathbf{p H}$, arterial $\mathbf{P}_{2}$, and FHF during the experiment. $\Delta \mathrm{pH}$, $\triangle F H F, \triangle \mathrm{PO}_{2} \mathrm{~A}$ : difference between baseline value and maximum change in $\mathrm{pH}$ units, beats/minute, $\mathrm{mmHg}$. 
and the response of the heart rate. The mean $\mathrm{pH}$ values in those two types are significantly different $(p<0.005)$ in spite of the small number of cases. Similarly, three different response types of the fetal aortic blood pressure can be described:

a) increase in blood pressure only

b) initial rise in pressure followed by a decrease

c) decrease in blood pressure only.

However, the individual values cover a wide range and the three groups are statistically not different from each other.

In tab. 9 we examined whether the extent of the heart rate deceleration correlated with the extent of acidosis or hypoxia. The table shows that this is not so. The median heart rate deceleration is 80 beats per minute. The decrease in $\mathrm{P}_{\mathrm{O} 2}$ of the cases with a deceleration of more than 60 beats per minute is not different from that in cases with a lesser deceleration. This applies also to the extent of the acidosis.

\section{Discussion}

\subsection{Discussion of methods}

The financial, instrumental and personnel complexity of such experiments often results in case numbers too small for statistical evaluations.

For each experiment the influence of the operation and the anesthesia upon the fetus has to be considered. The role of the anesthesia can be assumed to be minimal because the ewes initially received only a small dose of a barhiturate and were then kept in superficial anesthesia with a muscle relaxant. Hoivever, some anesthetic effects upon the fetus must be assumed, in particular, those of the regulation of its cardiac frequency. Of greater importance and of greater individual variation, however, is the operative stress. Umbilical cord manipulations are particularly unphysiological and lead to localized and uncontrollable vascular spasms which are reversible to varying extents. Tab. 7 demonstrates this with individually highly variable umbilical flow rates before the experiment. Therefore, we cannot make conclusive statements about umbilical-cord blood flow: The measurement of umbilical blood flow with electromagnetic flow meters is associated with some methodological flaws[20]. Our results are considerably lower than those of other authors $[2,20$, $26,32,36]$. It must be taken into account that we measured the flow in only one umbitical vesset, therefore; statements about the total umbilical perfusion cannot be made. It cannot be assumed that flow changes in both vessels necessarily occur in a similar way.

Corrections must also be applied to the biochemical changes because it cannot be assumed that the maxi- mum change was recorded in each instance. The $\mathbf{P O}_{2}$ value in particular can change very rapidly $[8,24]$ and continuous measurements are required for a complete documentation of the changes. The correction of the measured $\mathrm{PO}_{2}$ value to the actual $\mathrm{pH}$ value was done with the factor reported by Disl for human blood [21]. While this is basically not justifiable, it is still better than no correction at all because the basis for comparison is improved. Bartels and Harms [5] have shown that for several animal species this factor has the least deviation in the range of $20 \%$ to $80 \%$ oxygen saturation if the $\mathrm{PO}_{2}$ values for the $\mathrm{pH}$ range of 7.2 to 7.6 are corrected to a $\mathrm{pH}$ of 7.4.

These same problems apply to oxygen saturation values derived from nomograms. Meschia and coworkers [35] and DAwEs [20] have reported oxygen saturation curves for fetal lambs for which the $P_{50}$ values are on either side of the $P_{50}$ of the oxygen dissociation curve published by THEws and coworkers [43] for human fetal blood. Therefore we have adopted THEws' curve and our saturation values are corrected to a $\mathrm{pH}$ of 7.4.

Important objections may be raised against experiments with acute preparations. We were unable to maintain standardized experimental conditions as acute experiments are generally unsuitable for this purpose. Similarily, our animals were not selected as we do not have the enviable conditions enjoyed by DAwEs, who can work with animals bred and kept under standard conditions.

However, our objective was not to investigate fetal reactions under conditions which might be considered optimal by physiologists and which can only be carried out with chronic preparations involving selected animal material. Under those circumstances all parameters but one would be kept constant and the fetal response to the change of this one parameter would be investigated. We recognize the advantages of such procedure and envy scientists having the necessary experimental conditions at their command. We would like to point out that we wanted to simulate acute situations, such as they might occur in the delivery room where there are no standardized conditions and where intra partum stresses often occur acutely and may be quickly reversed (e. g. after a contraction). Therefore, we attempted to examine a wide spectrum of various fetal basal states for their response to the most important fetal stress, namely, lack of oxygen.

We consider an advantage of our experimental design that the fetus remains in utero. HEYMANN and RUDOLPH [27] have shown that the exteriorization of the fetus results in hemodynamic changes.

\subsection{Discussion of the results}

The fetal response to hypoxia has been investigated extensively $[3,6,10,12,15,19,23,30$, $31,33, \cdots 34,37,42]$. However, fetal hypoxia in these reports was caused exclusively by maternal hypoxia. This results in changes unlike those found in clinically relevant hypoxia states (e. g. placental insufficiency, poor uterine per- 
fusion): an increase in maternal catecholamines occurs $[15,16,42]$, which we were also able to demonstrate in two cases [40]. In addition there are considerable maternal biochemical and hemodynamic changes such as a rise in blood pressure and vasoconstriction.

The transfer of maternal catecholamines to the fetus has not been described in previous literature [17]. While we were able to demonstrate in one case (fig. 2) that following the injection of radioactive adrenalin and noradrenalin into the ewe there was activity in the fetal blood, we cannot prove that this corresponded to biologically active catecholamines.

It is not known whether the cause of the fetal hypoxia is related to the type of fetal response. Our ligature experiments simulated the decrease of maternal oxygen supply as it might be found in shock, during a contraction, with physical exertion, and with the vena cava syndrome. The hypoxia experiments leading to a rise in maternal blood pressure and maternal vasoconstriction simulated a lack of oxygen as it may occur during poor anesthesia for a caesarian section or as it may be found chronically in patients with toxemia (vasoconstriction, rise in blood pressure, poor uterine and placental perfusion, decreased oxygen supply to the fetus). The result, in the form of a decreased oxygen supply, is identical in both forms; however, the transfer of maternal active catecholamines to the fetus with resulting fetal cardiac and vascular reactions cannot be excluded.

With the small number of experiments we could not demonstrate any differences and we shall consider the results together.

\subsubsection{Biochemical results}

The decrease of fetal arterial and venous $\mathbf{P}_{\mathbf{O}_{2}}$ can be demonstrated only if samples are obtained at very short intervals. Fetal hypoxemia occurs very quickly and is reversible just as quickly and completely after cessation of a stress. This has been shown by WALKER and coworkers [44], and RENOU and coworkers [38], as well as in our own laboratory [8]. We believe that we have demonstrated only in a few cases the full extent of the fetal hypoxemia. Most samples were ob- tained during the subsequent rise of $\mathrm{P}_{\mathrm{O} 2}$ or shortly thereafter. In order to demonstrate the maximal hypoxemia, continuous $\mathrm{P}_{\mathrm{O}_{2}}$ measurements are required. Our $\mathrm{P}_{\mathrm{O} 2}$ values measured during acute hypoxia were found to be almost always above the limits given by BRINKMAN et al. for "severe" fetal hypoxia. However, our measurements represent only rarely the very transient maximum response, so that a severe hypoxia with corresponding cardiovascular reactions cannot be excluded.

As expected, fetal acidosis occurs later than hypoxia. Apparently, even brief hypoxia leads to a certain amount of anaerobic glycolysis, with the formation of acidic radicals whose presence can be demonstrated in the blood afterwards. Continuous measurements are probably not necessary here nor is the measurement of the $\mathrm{pH}$ necessary at the moment of stress. Therefore, if decelerations in cardiac frequency are observed clinically, indicating a disturbed gas exchange between mother and fetus, micro-blood sampling for the documentation of the fetal stress should be done 3-4 minutes after the occurrence. While the fetal $\mathrm{P}_{\mathrm{O}_{2}}$ at this time may have become normal again, acidosis is always an indication of previous lack of oxygen.

\subsubsection{Blood pressure}

There is no uniform opinion about blood pressure changes represented in previous literature, including the work done by the groups of Dawes and Assali. This can be explained largely by the difference in experimental procedures. Variations in the findings are quite large, not only from one experimental team to another, or from one series of experiments to another, but also between individual experiments. The greater the number of parameters measured, the more difficult it is to establish a series with comparable basal conditions yieIding consistent results. We shall address ourselves to fetal changes resulting from fetal hypoxia produced by maternal hypoxia, in particular changes in blood pressure, cardiac frequency, umbilical blood flow, and vascular resistance in the umbilicalplacental system.

The rise in maternal blood pressure in the hypoxia experiments is caused by the release of 
catecholamines $[15,40,47]$ and/or the stimulation of chemoreceptors. We were able to measure an increase in maternal catecholamine excretion by $50 \%$ and $500 \%$ respectively in two experiments [40].

BRINKMAN et al. [14] did not show a significant increase in maternal blood pressure; however, their hypoxia experiments were extended over periods of 30 and 15 minutes, with the animals breathing $13 \%$ and $6 \% \mathrm{O}_{2}$ respectively. Obviously, our experimental conditions are of a more acute nature because they were meant to simulate acute intra partum disturbances.

The changes in fetal blood pressure are not consistent $[10,14,20,34]$. Fetal blood pressure is regulated by the cardiac minute volume and peripheral vascular resistance. Blood pressure will rise or fall according to the relative condition of either parameter. A change in cardiac volume might be caused by hypoxic myocardial damage [23] or by decreased blood return [14]. It was observed that end-diastolic pressures in either ventricle showed little change; therefore, it is more likely that a decreased cardiac volume is caused by decreased venous return rather than by diminished cardiac contractility resulting from hypoxia.

BRINKMAN and coworkers have made the interesting observation that in hypoxia the placental vascular resistance rises by $11 \%$ to $17 \%$ and that of the so-called umbilical sinus by $24 \%$ to $66 \%$. This means that in hypoxia the bloodreturn via the umbilical vein, which accounts for about $50 \%$ of the total return, can be decreased or delayed so that the constriction of the umbilical sinus causes a portion of the venous blood to flow into the liver or so that it may be retained in the placenta instead of taking the low-resistance pathway through the sinus venosus.

The alternative mechanism which regulates blood pressure is related to the peripheral resistance. Catecholamines released by hypoxia $[15,40,42]$ may cause a rise in blood pressure mediated by vasoconstriction. However this vasoconstriction is not necessarily ubiquitous nor uniform.

We are primarily concerned with the circulation in the umbilical cord. Since the decrease of placental perfusion was proportionately greater than the decrease in blood pressure, an umbilical-placental vasoconstriction must be considered. As a result, a pooling of the blood in the placenta occurs, followed by a decrease in the return of blood to the heart. It is assumed that the vasoconstriction is localized in the umbilical sinus just before the umbilical vein joins the ductus venosus [13]; the vasoconstriction is certainly located on the venous side of the circulation. Besides the vasoconstriction in the venous portion, possibly mediated by catecholamines, a direct hypoxic vasodilation may play a role because a decrease in the partial pressure of oxygen has a local vasodilating effect [29]. Finally, the pooling of the blood in the placenta may be enhanced by cardiac decompensation because if central venous pressure exceeds the pressure in the umbilical vein, blood is returned via the umbilical vein to the placenta [19]. We observed this in three animals (H5, L6, L7). DAwEs [20] has demonstrated with a body-plethysmograph a decrease of the fetal volume of up to $8 \mathrm{ml}$ within 2 minutes after a fetal infusion of 0.5 to $1.0 \mathrm{mg} / \mathrm{kg} / \mathrm{min}$ of adrenalin or noradrenalin. The clinical picture of feto-placental transfusion with the resulting anemic fetus is well-known.

There was a variable fetal blood pressure response in our experiments. We were unable to demonstrate uniform relations between responses in blood pressure, blood flow, and cardiac frequency. We cannot comment on the umbilico-placental resistance because we did not measure pressures within the umbilical vessels. However, we have attempted to differentiate 3 different types of blood pressure responses (fig. 3) and to correlate them to various fetal basal states. This basal state is judged by the $\mathrm{pH}$ value because the $\mathrm{P}_{\mathrm{O} 2}$

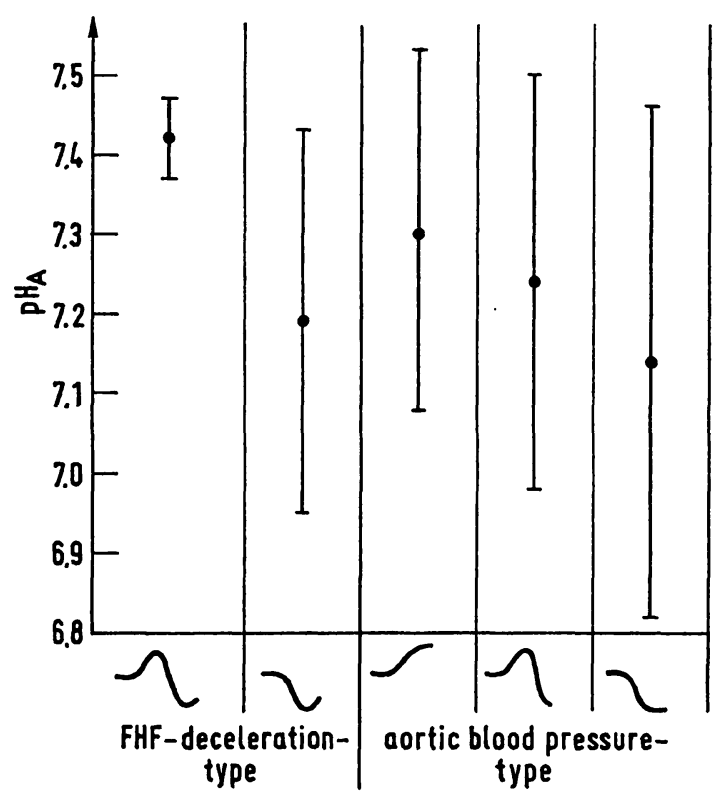

Fig. 3. The correlation between the response type of the fetal heart frequency (FHF) and the aortic blood pressure ( $\mathrm{P}_{\text {Aorta }}$ ) and the baseline $\mathrm{pH}$. Plotted are the mean and two standard deviations. 
spot samples did not appear suitable for this assessment; $\mathrm{pH}$ values are more reliable because they change more slowly. While the number of our observations is too small for statistical analysis, we have the impression that those fetuses which react with an initial or an exclusive rise in blood pressure are in a better basal condition than those in whom the hypoxia leads to an immediate decrease in blood pressure.

\subsubsection{Fetal heart frequency (FHF)}

Here again the response to hypoxia and ligature of the uterine artery depended on the baseline condition. Three different types of FHF response were seen:

\section{1. acceleration of FHF only}

2. initial acceleration followed by deceleration 3. deceleration only.

As seen in fig. 3 the fetal basal condition as defined by the $\mathrm{pH}$ evokes variable $\mathrm{FHF}$ responses. In the current series of experiments only two different deceleration patterns were seen in contrast to a series of experiments which will be published separately. Fetuses in whom the FHF rises initially and decreases later had a better baseline condition than those reacting with deceleration only. However, if the baseline $\mathrm{P}_{\mathrm{O} 2}$ value serves as the definition for the basal condition, this correlation is less obvious. More recent and in part unpublished results $[8,31]$ using larger numbers of experiments and continuous $\mathrm{P}_{\mathrm{O}_{2}}$ monitoring show that $\mathrm{P}_{\mathrm{O}_{2}}$ values may be useful as an indicator of the fetal condition.

This initial FHF acceleration from hypoxic stress has been examined only to a limited degree in the literature. MANN and co-workers [34] have described accelerations with later deceleration if the initial FHF was between 125 and $160 \mathrm{bpm}$, and deceleration exclusively if the initial FHF was above 160 . We conclude from their study that the tachycardia in their cases indicated some degree of hypoxia. However, an analysis of the FHF responsetypes according to the basal $\mathrm{pH}$ or $\mathrm{PO}_{2}$ values is not possible from the published data.

HoN [28] has described several episodes of brief acceleration which give the impression of a tachycardia because of some degree of superimposition. On the other hand the entire modern obstetric literature refers almost exclusively to the various deceleration types.

BRINKMAN and co-workers [11] have pointed out that the fetal heart responds with decelerations to the same stimuli which cause acceleration in adults. In classical obstetrics a fetal tachycardia was considered an indication of mild hypoxia.

is

Born, DAwes, and Motr showed in 1956 that FHF rises with light hypoxia [10]. As hypoxemia progresses - in particular as $\mathrm{O}_{2}$ saturation drops below $15 \%$ FHF decreases. BORN and co-workers postulate reflex mechanisms as the cause of the tachycardia and interpret the deceleration as being caused by a stimulation of chemoreceptors and/or a reactive triggering of the pressor reflex $[10,20]$. However, it is generally thought that a stimulation of chemoreceptors by hypoxia does not cause bradycardia, but rather tachycardia [29].

In contrast however, COMroE and MORTIMER [18] postulate the opposite response of the aortic and carotid chemoreceptors, with a net response to hypoxia consisting of tachycardia and hypertension. While the pathogenesis of FHF deceleration is still incompletely known, it is assumed that severe prolonged hypoxemia damages the myocardium directly by lack of oxygen.

According to our observations the fetal response to hypoxia does not appear to be different from that of the adult. In the first stage of adaptation the stimulation of the chemoreceptors by hypoxia excites the sympathetic nervous system causing a rise in cardiac frequency and fetal blood pressure. With continuing hypoxia the vasomotor centers and in particular the vagal nuclei are excited and the vasoconstrictors are consequently inhibited. As a result the cardiac frequency decelerates and the blood pressure drops. The adaptibility of the fetus is now exhausted and shock ensues. The transition from vagal excitation to vasomotor collapse is smooth $[9,24]$. Ultimately, hypoxemia leads directly to myocardial damage $[20,23,28]$.

If hypoxia occurs in a fetus in good baseline condition these stages of sympathetic stimulation - vagal stimulation. - collapse are experienced sequentially. If hypoxia occurs in a fetus in poor basal condition the FHF deceleration occurs immediately. Therefore we assume that the type of the FHF response allows conclusions to be drawn as to the original baseline condition of the fetus. This is corroborated by other observations [41]. Therefore, to describe an FHF response by the term "deceleration" is unsatisfactory because it does not take into consideration the initial acceleration. On the other hand we do not want to complicate the current discussion of nomenclature by the introduction of new terms as long as our findings have not been confirmed in other laboratories. 
Even though the type of the heart rate response permits one to draw conclusions as to the fetal condition this appears to apply less to the extent of the deceleration in cardiac frequency. MüLLER-Heubach et al. [37] have demonstrated a correlation between the extent of the fetal hypoxia and the extent of the deceleration.

However, they based their correlations on $\mathrm{P}_{2}$ values obtained from intermittent sampling. We have found that $\mathrm{PO}_{2}$ values obtained from spot samples do not record the extent of fetal hypoxemia correctly. Correlations based on this procedure have the inherent risk of recording the maximum decrease in $\mathrm{P}_{2}$ only by chance. Consequently, no correlation is demonstrable from our calculations. We believe that continuous $\mathrm{P}_{2}$ measurements must be utilized. On the other hand it appears to be a logical assumption that the fetal heart should decelerate in proportion to the

\section{Summary}

\section{Experimental design}

Experiments on 5 fetal lambs were carried out 7 to 14 days before term. The time of conception and thus the estimated time of birth were known accurately because of controlled ovulation. Thus experiments could be done on animals of comparable gestational age. The uterotomy was performed on ewes in which light anesthesia was induced with barbiturate and maintained with nitrous oxide $\left(\mathrm{O}_{2}: \mathrm{N}_{2} \mathrm{O}=\right.$ $1: 1)$. The fetuses were partially delivered briefly for the application of the measuring devices; otherwise they remained in utero during the experiments (fig. 1). The following measurements were carried out (tab. 1):

in the fetus: ECG

beat-to-beat cardiac frequency (FHF) aortic blood pressure

blood flow in the umbilical artery and vein $\mathrm{pH}, \mathrm{P}_{2}$, and $\mathrm{PCO}_{2}$ in the umbilical artery and vein

in the mother: blood pressure in the femoral artery arterial $\mathrm{pH}, \mathrm{PO}_{2}$, and $\mathrm{PCO}_{2}$.

In 7 experiments the ewe was rendered hypoxic by ventilating her with pure nitrous oxide (hypoxia experiments), in 8 experiments the uterine artery was compressed partially (ligature experiments) in order to reduce the utero-placental perfusion. This latter design attempted to simulate conditions during a uterine contraction.

The problems of this experimental design will be discussed in detail. The most important are:

a) the question whether results from experiments on anesthesized animals can be transferred to the human fetus

b) the disadvantages of the acute preparation as opposed to a chronic experiment. However, we dealt with questions of acute emergency situations of the fetus as they occur in the delivery room. fetal hypoxemia. With our limited observations we do not want to exclude this possible interrelation, particularly since MüllER-HEUBACH through simultaneous tocography has been able to help establish the timing of the maximum hypoxia.

\subsubsection{Umbilical blood flow}

The electromagnetic measurements of umbilical blood flow yielded no uniform results. As commented on above, conclusions cannot be drawn and we publish our data only to demonstrate that electromagnetic flow measurements on isolated umbilical vessels may easily give results which cannot be interpreted [20]. In isolated cases it was seen that the blood flow in the umbilical vein may be reversed. c) the surgical trauma to the fetus

d) the technical inadequacies of the measurement of blood flow with electromagnetic flow meters and the inadequacies of the discontinuous $\mathrm{PO}_{2}$ measurements.

For these reasons only a few of the total number of experiments could be interpreted.

\section{Results}

Under both experimental conditions the fetuses reacted in a similar fashion; therefore the results will be discussed together. The possible transfer of maternal catecholamines released to the fetus in an active form during the hypoxia experiments cannot be excluded. We demonstrated the transfer of radioactively labelled adrenalin and noradrenalin in one case; this does not necessarily imply biological activity in the fetal circulation (fig. 2).

A decrease of the fetal $\mathbf{P O}_{\mathbf{2}}$ in both experimental designs (tab. 5) can be demonstrated only if sampling occurs at very short intervals and during the stress. In contrast to the $\mathrm{pH}$ changes (tab. 3 ) with their time lag, $\mathrm{Po}_{2}$ changes are very transient. Continuous $\mathrm{PO}_{2}$ measurements are therefore required if the time relation to other biochemical and hemodynamic changes or cause-and-effect relations are to be investigated. The clinical consequence is that micro-blood examination of the fetus should not be done during or immediately after a deceleration of cardiac frequency indicates fetal hypoxemia, but 3 to 4 minutes later. The $\mathrm{pH}$ indicates satisfactorily the extent of the hypoxemia which is usually more or less reversible and often recurs.

The fetal blood pressure showed varying responses (fig. 3). The possible reasons for this are to be sought in changes of cardiac volume and vascular resistance caused by the hypoxemia which may react in either direction. An important regulator of cardiac volume is the heart rate which almost always decelerates during hypoxia. This 
causes a decrease of cardiac volume and consequently a decrease in blood pressure. But, however, the blood pressure may rise when hypoxia causes catecholamine release with a resulting vasoconstriction. Therefore, the net effect on the blood pressure is the result of two opposing factors. This explanation is necessarily an oversimplification.

Three different types of fetal blood pressure response can be recognized (tab. 7); they correlate probably with the fetal baseline $\mathrm{pH}$ value (the number of the experiments is too small and the scatter too large for statistical significance). With a good basal state of the fetus there is a rise in blood pressure only; with a somewhet poorer basal state or a prolonged stress this is followed by a decrease in blood pressure. As a result a dual response of the blood pressure is seen. With a primary poor basal condition as defined by the $\mathrm{pH}$, the blood pressure drops immediately.

A similar response is seen with fetal heart frequency (FHF) for wich we differentiated only two types in our current series of experiments:

a) initial acceleration followed by deceleration

b) immediate deceleration.

With a favorable basal state as defined by the preexperimental $\mathrm{pH}$, type $\mathrm{A}$ is found, with a poorer basal condition, type $\mathrm{B}$.

Keywords: Animal experiments, hypoxia, circulation, blood pressure, adaptation, fetus, ligature experiments, oxygen, oxygen tension

Zusammenfassung

Die Auswirkungen einer experimentellen akuten Verminderung der Uterusdurchblutung und einer mütterlichen Hypoxie auf den Feten

\section{Versuchsanordnung}

Es wurden 15 Versuche an fünf Schaf-Feten 14 bis 7 Tage vor dem errechneten Wurftermin durchgeführt. Der Konzeptions- und damit der Wurftermin wurde durch Ovulationsauslösung festgelegt, so daß die Versuche an Tieren vergleichbarer Tragzeit vorgenommen werden konnten. Die Muttertiere wurden nach Barbiturat-Einleitung in oberflächlicher Lachgas-Narkose $\left(\mathrm{O}_{2}: \mathrm{N}_{2} \mathrm{O}=1: 1\right)$ uterotomiert. Der Fet wurde nur kurz und partiell entwickelt, um die Meßköpfe anbringen zu können, und blieb während der Versuche intrauterin.

Es wurden gemessen:

Beim Feten: $\quad$ EKG

beat-to-beat Herzfrequenz (FHF)

aortaler Blutdruck

Durchblutung in Art. und Vena umbilicalis

$\mathrm{pH}, \mathrm{PO}_{2}$ und $\mathrm{PCO}_{2}$ in Art. und Vena umbilicalis

Bei der Mutter: Blutdruck in der Art. femoralis $\mathrm{pH}, \mathrm{PO}_{2}$ und $\mathrm{PCO}_{2}$ arteriell.

Bei 7 Versuchen wurde das Muttertier durch Beatmung mit reinem Lachgas hypoxiert (Hypoxie-Versuche), bei 8 die Art. uterina mit einer Drosselschlinge komprimiert (Ligatur-Versuche), um die utero-plazentare Durchblu-
The causes for the different responses of blood pressure and FHF are thought to be related to the baseline condition of the cardiovascular regulatory system. As in the adult organism, hypoxia stimulates primarily peripheral chemoreceptors and the sympathetic nervous system and thus causes, either directly or through catecholamine release, an increase of blood pressure and FHF. With a persisting stress or with a poorer baseline condition (which in the clinical situation are probably identical) there is a vagus stimulation by the vasomotor center with a resulting decrease in FHF and blood pressure (inhibition of vasoconstrictors). Finally the condition gradually leads to collapse and the damage of the myocardium.

For clinical applications the type of the FHF response to uterine contraction to a certain extent permits conclusions as to the fetal basal state to be drawn.

There were no consistent correlations between the extent of the hypoxia or acidosis and the extent of the FHF deceleration.

For methodological reasons the results from electromagnetic measurements of the blood flow cannot be interpreted. In isolated cases a reversal of the blood flow in the umbilical vein was seen and was compared with a fetal-placental transfusion in the human fetus. minderung tung zu reduzieren. Wir stellen uns vor, daß letztere Versuchsanordnung in etwa den Bedingungen unter der Wehe entspricht.

Die Versuchsanordnung ist aus verschiedenen Gründen, die ausführlich diskutiert werden, problematisch. Die wichtigsten sind:

a) die fragliche Ưbertragbarkeit" von Ergebnissen aus Experimenten am narkotisierten Tier auf den menschlichen Feten,

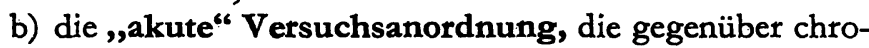
nischen Experimenten unbestreitbare Nachteile hat. Allerdings handelt die Fragestellung von akuten, im Kreißsaal auftretenden Notsituationen des Feten.

c) die operative Traumatisierung des Feten,

d) die technischen Unzulänglichkeiten der Durchblutungsmessung mit elektromagnetischen Meßgeräten und der diskontinuierlichen $\mathrm{PO}_{2}$-Messung.

Aus diesen Gründen konnten nur relativ wenige der insgesamt durchgeführten Experimente ausgewertet werden.

\section{Ergebnisse}

Bei beiden Versuchsanordnungen reagiert der Fet in ähnlicher Weise, so daß die Ergebnisse gemeinsam besprochen werden können. Es wird jedoch die Frage aufgeworfen, ob die bei den Hypoxie-Versuchen ausgeschütteten mütterlichen Catecholamine als wirksame Substanzen auf 


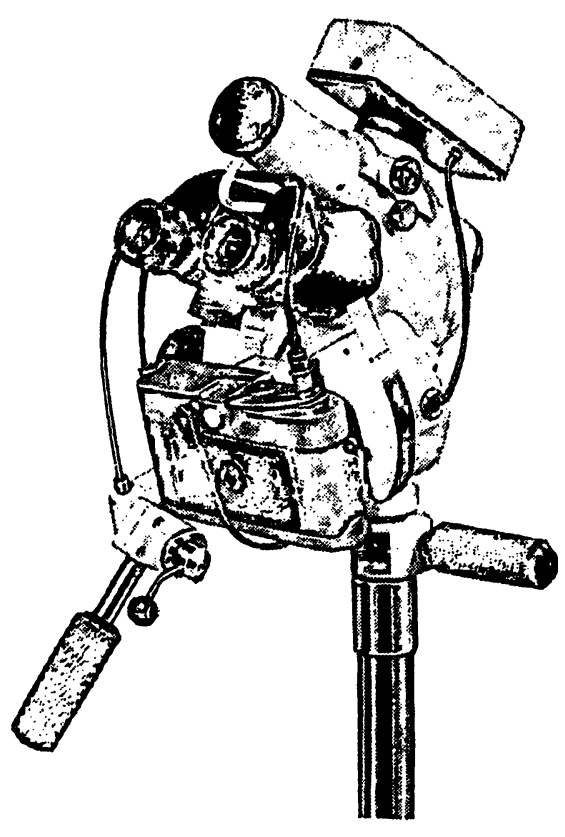

\title{
COLPOSCOPES AMNIOSCOPES
}

\author{
Colposcope magnifications $13.5 \mathrm{x}$ or \\ 13.5x and 50x \\ Stereo-Camera-Colposcopes \\ Mini-Colposcopes \\ The Hoffbauer Amnioscope \\ for the inspection with the naked eye \\ or with colposcopic magnification

\section{LEISEGANG}

1 Berlin 12 - Leibnizstraße 32 - Telefon (0311) 310471

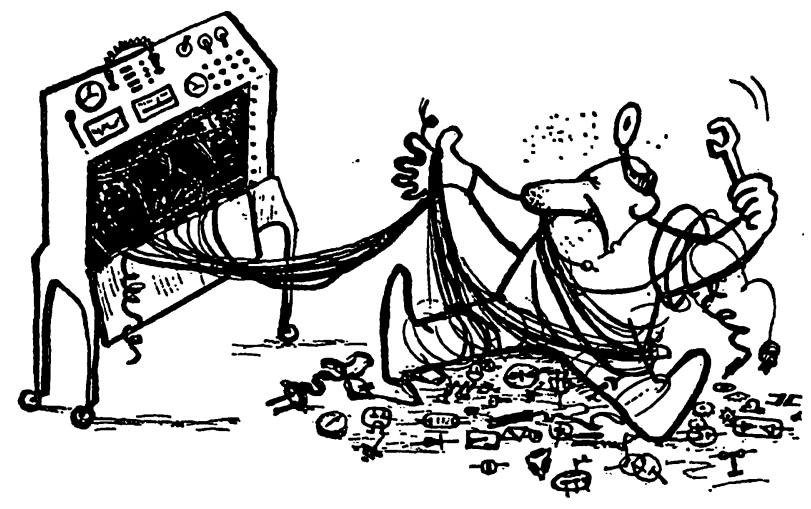

NEUERSCHEINUNG

Dr. Armin Schäffer

\section{Arzt aus Leidenschaft}

Heiteres und Kritisches

aus der großen weißen Welt

1972, 136 Seiten, Großformat, 75 Karikaturen Leinen DM 48,-

Die vielfachen ärztlichen Probleme einer Umbruchzeit in der Medizin finden in dieser Neuerscheinung bildhaften Ausdruck. Der zeichnerisch begabte Arzt schont seine Standesgenossen nicht, hilft ihnen indessen zu klarerer Einsicht in die Lage. Ein hervorragendes Geschienkwerk: von Arzt zu Arzt, vom dankbaren Patienten für den Behandler, von der Helferin oder Schwester für den Chef.

\section{J. F. LEHMANNS VERLAG MÜNCHEN}

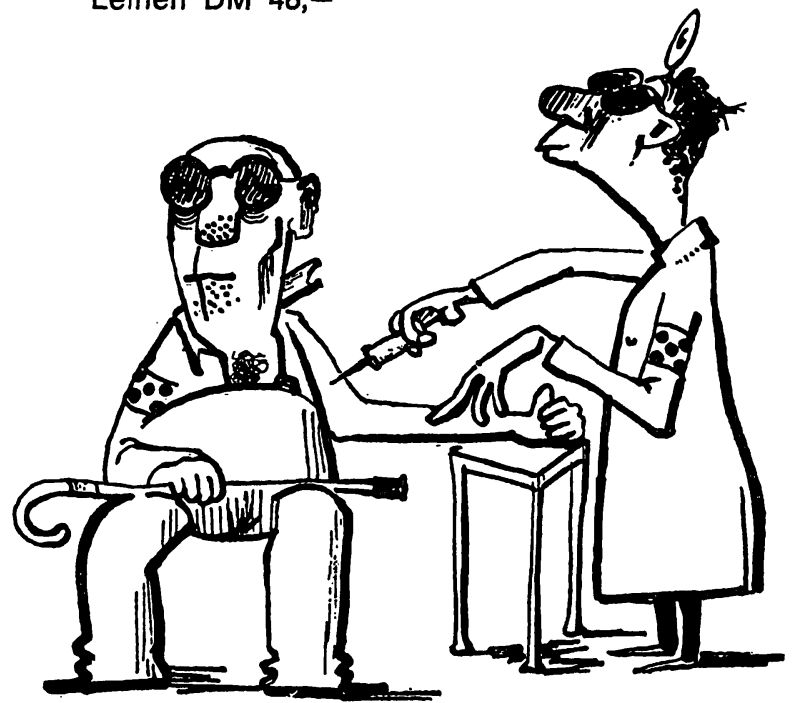




\section{Walter de Gruyter Berlin-New York}

\section{Zeitschrift}

\section{für Klinische Chemie und Klinische Biochemie}

Journal of

\section{Clinical Chemistry} and Clinical

\section{Biochemistry}

Organ der Deutschen Gesellschaft für Klinische Chemie

Responsible Editors:

Joachim Brugsch, Johannes

Büttner, Ernst Schütte

Edited with the collaboration of numerous german and foreign experts

From 1972: 12 issues per annum Appr. 768 pp. DM 290,-; $\$ 102.00$ 1973: Vol.11

\section{Hoppe-Seyler's}

\section{Zeitschrift}

\section{für Physiologische \\ Chemie}

Edited by $A$. Butenandt,

F. Lynen, G. Weitzel

With the collaboration of numerous experts.

Publikation: 12 issues per annum

DM 480,一; $\$ 169.00$

1973: Vol. 354
Edward Muntwyler

Elektrolytstoffwechsel

und Säure-Basen-

Gleichgewicht

Translated from the English by

Wolf-Diefer Thomitzek.

1973. 272 pp. 33 illus.

Boards DM 14,80; $\$ 5.20$

ISBN 3110039508

(Sammlung Göschen 7137)

\section{Hilde Götz}

\section{Immunologische Plasmaprotein- Diagnostik}

1973. XII + 240 pp. 106 illus. Bound DM 96,-; $\$ 33.75$ ISBN 3110037726

\section{H. Rainer Maurer}

\section{Disc Electrophoresis}

and Related Techniques of Polyacrylamide Gel Electrophoresis.

2nd revised and expanded edition. 1971. With 98 fig., 16 tables and 948 literature refer.

XVI + 222 pp.(with 1 Fould-out chart)

Bound DM 68,-; $\$ 24.00$

ISBN 3110034956

(Working Methods in Modern Science)

\section{Fischer-Werner}

\section{Autoradiography}

1971. $X+199$ pp. With 93 fig. and 14 tables.

Bound DM 64,-; $\$ 22.50$

ISBN 3110035235

(Working Methods in Modern Science)

\section{Karl Höll}

\section{Water}

Examination - Assessment Conditioning - Chemistry Bacteriology . Biology with the collaboration of HelmutPeter and Dietrich Lüdemann

Translated from the 5th German edition by M. R. F. Ashworth. 1972. XVIII + 389 pp. With 24 diagrams and 129 figures. Bound DM 76,-; $\$ 24.00$ ISBN 3110037289 
den Feten übergehen können. Wenn wir auch den Übertritt radioaktiv markierten Adrenalins und Noradrenalins in einem Fall nachweisen konnten (Abb. 2), so sagt das über die biologische Wirksamkeit im fetalen Kreislauf nichts aus.

Ein Abfall des fetalen $\mathbf{P o}_{2}$ bei beiden Versuchsanordnungen (Tab. 5) läßt sich nur nachweisen, wenn man in sehr kurzen Intervallen und während der Noxe untersucht. Im Gegensatz zu den pH-Veränderungen (Tab. 3), die erwartungsgemäß nachhinken, sind diejenigen des $\mathrm{PO}_{2}$ sehr flüchtig. Kontinuierliche $\mathrm{PO}_{2}$-Messungen sind daher angezeigt, weñn man die zeitlichen Relationen zu anderen biochemischen und haemodynamischen Wertänderungen oder kausale Beziehungen untersuchen will.

Für die Klinik ergibt sich die Folgerung, z. B. die Mikroblutuntersuchung des Feten nicht während oder unmittelbar nach einer Herzfrequenz-Dezeleration, die Ausdruck der fetalen Hypoxämie sein kann, vorzunehmen, sondern erst 3-4 Minuten später. Der pH-Wert gibt das Ausmaß der - meist mehr oder weniger reversiblen, aber häufig rezidivierenden - Hypoxämie befriedigend an.

Der fetale Blutdruck (Abb. 3) verhielt sich uneinheitlich. Die möglichen Gründe dafür beruhen auf der gleich- oder gegensinnigen Änderung des Herzzeitvolumens und des Widerstandes, die beide durch die Hypoxämie betroffen werden können. Ein wichtiges Regulativ des Herzzeitvolumens ist die Herzfrequenz, die unter der Hypoxie fast immer dezeleriert. Der u. a. darauf basierenden Verminderung des HZV mit konsekutivem Blutdruckabfall steht der Blutdruckanstieg gegenüber, der durch Hypoxie - Katecholamin-Freisetzung - Vasokonstriktion bedingt ist. Der resultierende Blutdruck ist das Ergebnis zweier gegenläufiger Einflüsse. Diese Darstellung ist stark vereinfacht.

Bei der fetalen Blutdruck-Reaktion lassen sich drei verschiedene Formen unterscheiden (Tab. 7), die wahrscheinlich Beziehungen zum fetalen Ausgangs-pH-Wert aufweisen (wegen der geringen Fallzahl und großen Streuung statistisch nicht gesichert). Bei guter Ausgangslage erfolgt ein reiner Blutdruckanstieg, der bei etwas schlechterer Ausgangssituation oder verlängerter Noxe von einem Absinken des Blutdrucks gefolgt ist. Das Resultat ist eine Doppelschwingung des Blutdrucks. Bei primär sehr ungünstiger Lage (definiert durch den pH-Wert) kọmmt es unmittelbar zum Absinken des Blutdrucks.

Ein ähnliches Verhalten bietet die fetale Herzfrequenz (FHF), bei.der wir in dieser Versuchsreihe nur zwei Typen unterscheiden konnten:

a) die initiale Akzeleration mit nachfolgender Dezeleration und

b) die unmittelbare Dezeleration.

Bei günstigerer Ausgangslage (definiert durch den $\mathrm{pH}$ Wert vor dem Versuch) findet man Typ A, bei. schlechterer Typ B.

Die Ursachen des unterschiedlichen Blutdruck- und FHFVerhaltens werden in der Ausgangslage des caräiovasculären Regelsystems gesehen. Dabei käme"ës bëi einer Hypoxie genau wie beim erwachsenen Organismǘs primär zu einer Stimulation peripherer Chemorezeptoren, zur Erregung des Sympathicus und damit direkt und/ oder über eine Catecholamin-Freisetzung zum Anstieg von Blutdruck und FHF. Bei fortbestehender Noxe oder primär schlechterer Ausgangslage (was in praxi identisch sein dürfte) wird über das Vasomotorenzentrum der Vagus erregt und es resultieren FHF- und BlutdruckAbfall (Hemmung des Vasokonstriktoren-Tonus). Schließlich geht der Zustand fließend in einen Kollaps und in eine Schädigung des Myocards über.

Für die Klinik vermuten wir, daß FHF-Antwort auf eine Wehe zum Beispiel, in gewissem Umfang auf die fetale Ausgangslage schließen können. Zwischen dem Ausmaß der Hypoxie oder der Azidose, und dem der FHF-Dezeleration konnten keine sicheren Beziehungen nachgewiesen werden.

Die Ergebnisse der elektromagnetischen Durchblutungsmessungen sind aus methodischen Gründen nicht zu verwerten. In Einzelfällen wurde eine Strömungsumkehr in der Vena umbilicals beobachtet und mit der fetoplazentaren Transfusion des menschlichen Feten verglichen.

Schlüsselwörter: Tierexperimente, Sauerstoff, Sauerstoff-Messung, Blutdruck, Herzschlagregistrierung, Fetus, SäureBasen-Haushalt.

\section{Resumé}

Les effets de la réduction brutale de la perfusion utérine et de l'hypoxie maternelle expérimentales sur le foetus

\section{Méthode d'expérimentation}

L'expérimentation a été réalisée sur 5 foetus de mouton 7 à 14 jours avant le terme. La date de conception donc le terme étaient connus avec précision grâce aủ contrôle de l'ovulation. Ainsi l'expérimentation a pu être faite pour des animaux d'âges gestationnels comparables. L'hystérotomie a été réalisée sur des brebis chez qui une anesthésie légère avait été induite par un barbiturique et maintenue par du protoxyde d'azote. Les foetus étaient partiellement extraits quelques instants pour la mise en place des appareils de mesure; par ailleurs, ils restaient in utero pendant l'expérience (fig. 1). On réalisait les mesures suivantes (tab. 1):

Pour le foetus: électrocardiogramme rythme cardiaque ,instantanéc pression sanguine aortique flux sanguin dans l'artère et dans la veine ombilicales.

$\mathrm{pH}, \mathrm{PO}_{2}$ et $\mathrm{PCO}_{2}$ dans l'artère et dans la veine ombilicales. 
Pour la mère: la pression dans l'artère fémorale $\mathrm{pH}, \mathrm{PO}_{2}$ et $\mathrm{PCO}_{2}$.

Dans 7 expériences la brebis a été rendue hypoxique en lui donnant du protoxyde d'azote pur (expérience sur l'hypoxie), dans 8 expériences l'artère utérine a été comprimée partiellement (expérience avec ligature) afin de réduire la perfusion utéro-placentaire. Cette dernière était destinée à simuler les conditions accompagnant une contraction utérine.

Les problèmes de cette méthode d'expérimentation seront exposés en détail. Les plus importants sont:

a) De savoir si les résultats obtenus à partir de l'expérimentation sur animal anesthésié peuvent être transposés au foetus humain.

b) Les inconvénients de la préparation pour de courtes périodes de temps sont opposés à ceux de l'expérimentation pour de longues périodes. Cependant, nous avons été confrontés avec des problèmes d'urgence pour le foetus tels qu'ils se rencontrent en salle d'accouchement.

\section{c) Le traumatisme chirurgical pour le foetus.}

d) L'imperfection technique de la mesure du flux sanguin avec les appareils de mesure électromagnétiques et l'imprécision de la mesure discontinue de la $\mathrm{P}_{2}$.

Pour ces raisons, quelques-unes seulement de l'ensemble des expériences ont pu être interprétées.

\section{Résultats}

Dans les deux conditions expérimentales les foetus ont réagi de façon identique; les résultats seront donc exposés ensemble. La possibilité d'un transfert de catécholamines maternelles libérées pendant les expériences d'hypoxie sous une forme active sur le foetus ne peut pas être exclue. Nous avons démontré le passage d'Adrénaline et de Noradrénaline marquées par des élèments radioactifs dans un cas, ce qui n'implique pas nécessairement une activité biologique, dans la circulation foetale (fig. 2).

Une diminution de la $\mathbf{P}_{2}$ foetale dans les deux expérimentations (tab. 5) peut-être mise en évidence seulement si les prélèvements sont réalisés à des intervalles de temps très courts et pendant l'agression. A la différence des variations de $\mathrm{pH}$ qui apparaissent avec un certain retard, les variations de $\mathrm{Po}_{2}$ sont très éphémères. $\mathrm{La}$ mesure continue de la $\mathrm{P}_{2}$ est donc nécessaire si l'on veut étudier les relations dans le temps avec les autres variations biochimiques et hémodynamiques et les relations de cause à effet.

La conséquence clinique de ceci est que l'analyse du sang des foetus par microméthode ne devrait pas être faite pendant ou immédiatement après une décélération cardiaque foetale indiquant une hypoxie foetale mais 3 à 4 minutes plus tard. Le $\mathrm{pH}$ indique de façon satisfaisante l'importance de l'hypoxémie qui est habituellement plus ou moins réversible et souvent réapparaît.

La pression artérielle foetale a montré des réponses variables (fig. 3). Les raisons possibles de ce fait doivent être recherchées dans les variations du débit cardiaque et de la résistance vasculaire dues à l'hypoxémie qui peut réagir dans l'une ou l'autre direction. Un élément de régulation important pour le débit cardiaque est la fréquence cardiaque qui diminue presque toujours pendant l'hypoxie, qui entraîne une diminution du débit cardiaque et par conséquent une diminution de la pression artérielle. Par contre, la pression artérielle peut s'élever quand l'hypoxie entraîne une libération de catécholamine avec la vasoconstriction qui en résulte. Donc, l'effet net sur la tension artérielle est le résultat de deux facteurs opposés. Cette explication est nécessairement trop simplifiée.

On peut distinguer trois types différents de réponse de la pression artérielle foetale (tab. 7); elles sont probablement en corrélation avec la valeur de base du $\mathrm{pH}$ foetal (le nombre d'éxpériences est trop petit et la répartition trop large pour avoir une signification statistique). Avec un bon état de départ du foetus il se produit seulement une élévation de la pression artérielle; avec un état de départ moins bon ou une agression prolongée il se produit une baisse de la pression artérielle. Il semble qu'il y ait une dualité de la réponse de la pression artérielle. Avec des conditions de départ mauvaises montrées par le $\mathrm{pH}$, la pression artérielle chute immédiatement.

On trouve une réponse identique avec le rythme cardiaque foetal (FHF) pour lequel nous distinguons seulement deux types dans cette série d'expériences:

a) accélération initiale suivie par une décélération.

b) Décélération immédiate.

Avec un état de départ favorable comme le montre la mesure du $\mathrm{pH}$ avant l'expérience, on trouve le type a, avec un état de départ moins bon le type b.

On pense que les causes des différentes réponses de la pression artérielle et du rythme cardiaque foetal sont en relation avec les conditions de base du système de régulation cardio-vasculaire. Comme dans un organisme adulte, l'hypoxie stimule d'abord les chémorécepteurs périphériques et le système sympathique et donc entraîne soit directement soit par la libération de catécholamine une élévation de la pression artérielle et du rythme cardiaque foetaux. Avec une agression qui persiste ou avec un mauvais état de départ (il y a en clinique probablement des conditions identiques) il se produit une stimulation du vague par le centre vasomoteur avec pour résultat une diminution du rythme cardiaque foetal et de la pression artérièlle (inhibition des vasoconstricteurs). Finalement l'état se modifie progressivement vers le collapsus et l'altération du myocard.

Nous supposons pour l'application clinique que le type de réponse du rythme cardiaque foetal permet dans une certaine mesure des conclusions quant à l'état de départ du foetus.

Il n'y avait pas une corrélation significative entre l'étendue de l'hypoxie ou de l'acidose et l'importance des décélérations.

Pour des raisons de méthode les résultats de la mesure électromagnétique du flux sanguin ne peuvent pas être interprétés. Dans des cas isolés une inversion du flux sanguin dans la veine ombilicale a été notée et ressemblait à la transfusion foeto-placentaire chez le foetus humain. 


\section{Mots-clés:}

Relations foeto-maternelle, Physiologie foetale, Expérimentation animale/Brebis/Foetus, $\mathrm{PO}_{2} / \mathrm{PCO}_{2} / \mathrm{pH}$, Débit sanguin, Perfusion sanguine/Compression cordon/Artère utérine, Hypoxie matcrnelle, Catécholamines/Passage transplacentaire.

\section{Acknowledgement}

The authors acknowledge the generous financial, instrumental and personnel support by Farbwerke Hoechst AG (PD Dr. Vogel), and Hewlett Packard (Mr. Gentner).

\section{Bibliography}

[1] Acheson, G. H., G. S. Dawes, J. C. Motr: Oxygen consumption and the arterial oxygen saturation in foetal and newborn lamb. J. Physiol. 135 (1957) 623

[2] Assali, N. S., L. Rauramo, T. Peltonen: Measurement of uterine blood flow in uterine metabolism. Amer. J. Obstet. Gynec. 79 (1960) 86

[3] Assali, N. S., J. A. Morris, R. W. Smith, W. A. Manson: Studies on ductus arteriosus circulation. Circulation Res. 13 (1963) 478

[4] Assali, N. S.: Biology of gestation. Vol. II: The fetus and neonate. Academic Press, New York-London 1968

[5] Bartels, H., H. Harms: Sauerstoff-Dissoziationskurven des Blutes von Säugetieren. Pflüg. Arch. ges. Physiol. 268 (1959) 334

[6] Behrman, R. E., M. H. Lees, E. N. Peterson, C. W. DE LANNoY, A. E. SEEDs: Distribution of the circulation in the normal and asphyxiated fetal primate. Obstet. and Gynec. 108 (1970) 956

[7] Berg, D., K. Hammacher, J. Schulz, K. Wernicke, R. MuschaweCK, K. Gärtner, K. Bonath, W. GruNER, R. SChuler: Arbeitshypothese zur Genese der Herzfrequenzalterationen - Beobachtungen an ausgetragenen Schaf-Feten. In: Saling E., F. J. Schulte: Perinatale Medizin Band II, 3. Deutscher Kongreß für Perinatale Medizin - Thieme, Stuttgart 1972

[8] Berg, D., J. Schulz, K. Wernicke, A. Huch, R. HuCH: Kontinuierlich bestimmte Sauerstoffpartialdrucke und Herzfrequenz des Schaf-Feten und ihre Beeinflußbarkeit über die Mutter (Hypoxie, placentare Ischämie, Pharmaka). 3. Europ. Kongr. f. Perinat. Medizin, Lausanne, 1972

[9] Bolton, D. P. G., K. W. Gross, D. V. Eitzman, J. KeLLY: The oxygen uptake and pulmonary blood flow during resuscitation from asphyxia in foetal and adult. sheep. J. Physiol. 205 (1969) 417

[10] BorN, G. V. R., G. S. Dawes, J. C. Mott: Oxygen lack and autonomic nerve nervous control of the foetal circulation in the lamb. J. Physiol. 134 (1956) 149

[11] Brinkman, C. R., C. Ladner, P. Weston, N. S. Assali: Baroreceptor functions in the fetal lamb. Amer. J. Physiol. 217 (1969) 1346

[12] Brinkman, C. R.: Umbilical blood flow and fetal oxygen consumption. Clin. Obstet. Gynec. 13 (1970) 565
[13] Brinkman, C. R., T. H. Kirschbaum, N. S. Assali: The role of the umbilical sinus in the regulation of the placental vascular resistance. Gynec. Invest. 1 (1970) 115

[14] Brinkman, C. R., P. Weston, T. H. Kirschbaum, N. S. Assali: Effects of maternal hypoxia on fetal cardiovascular hemodynamics. Amer. J. Obstet. Gynec. 108 (1970) 288

[15] Comline, R. S., M. Silver: The release of adrenaline and noradrenaline from the adrenal glands of the foetal sheep. J. Physiol. 156 (1961) 424

[16] Comline, R. S., I. A. Silver, M. Silver: Factors responsible for the stimulation of the adrenal medulla during asphyxia in the foetal lamb. J. Physiol 178 (1965) 211

[17] Comline, S. R., I. A. Sirver: Personal communication, August 1971

[18] Comroe, J. H., L. Mortimer: The respiratory and cardiovascular responses of temporally separated aortic and carotic bodies to cyanide, nicotine, phenyldiguanide and serotonin. J. Pharm. Exper. Ther. 146 (1964) 33

[19] Dawes, G. S.: Changes in $\mathrm{O}_{2}$ supply within the foetal lamb. J. Physiol. 159 (1961) 44

[20] Dawes, G. S.: Foetal and neonatal physiology. Year Book Medical Publishers, Chicago 1968

[21] Dili, D. B., A. Graybiel, A. Hurtado, A. Taquini: Der Gasaustausch in den Lungen im Alter. Z. Alternsforsch. 2 (1940) 20

[22] Dilts, P. V., C. R. Brinkman, T. H. Kirschbaum, N. S. Assalr: Uterine and systemic hemodynamic interrelationships and their response to hypoxia. Amer. J. Obstet. Gynec. 103 (1969) 138

[23] Downing, S. E., N. S. Talner, T. H. Gardner: Influences of arterial oxygen tension and $\mathrm{pH}$ on cardiac function in newborn lamb. Amer. J. Physiol. 211 (1966) 1203

[24] Fortmeyer, H. P., D. Berg, K. Bonath, A. KirschNER: Brunstsynchronisation und Trächtigkeitsdiagnose bei Schafen. Dtsch. Tierärztl. Wobl. 79 (1972) 49

[25] HAMMACHER, K.: Elektronische Geburtsüberwachung. Med. Klin. 64 (1969) 1846

[26] Hellegers, A. E., E. E. Armstead, C. E. Thomas, A. M. Burnett, T. J. Magovern, P. D. Bruns: Effect of fetal metabolic acidosis upon oxygen environment. Amer. J. Obstet. Gynec. 105 (1969) 786 
[27] Heyman, M. A., A. M. Rudolph: Effect of exteriorization of the sheep fetus on it's cardiovascular function. Circul. Res. 21 (1967) 741

[28] Hon, E. H.: An atlas of fetal heart rate patterns. Harty Press. Inc., New Haven, Connecticut 1968

[29] KeIded, W. D.: Kurzgefaßtes Lehrbuch der Physiologie. Thieme, Stuttgart 1970

[30] Longo, L. D., G. G. Power: Analyses of $\mathrm{P}_{2}$ and $\mathrm{PCO}_{2}$ differences between maternal and fetal blood in the placenta. J. appl. Physiol. 26 (1969) 48

[31] Longo, L. D., G. G. Power, R. E. Forster: Placental diffusing capacity for carbon monoxide at varying partial pressures of oxygen. J. appl. Physiol. 26 (1969) 360

[32] Makowski, E. L., G. Meschia, W. Droegemueller, F. C. Battaglia: Measurement of umbilical arterial blood flow to the sheep placenta and fetus in utero. Circulation Res. 23 (1968) 623

[33] ManN, L. I.: Effects in sheep of hypoxia on levels of lactate, pyruvate and glucose in blood of mothers and fetus. Pediat. Res. 4 (1970) 46

[34] ManN, L. I., J. W. Prichard, D. Symmes: EEG, ECG and acid-base observations during acute fetal hypoxia. Amer. J. Obstet. Gynec. 106 (1970) 39

[35] Meschia, G., A. Hellegers, J. N. Blechner, A. S. Wolkoff, D. H. Barron: A comparison of the oxygen dissociation curve of the bloods of maternal, fetal and newborn sheep at various pHs. Quart. J. Exp. Physiol. 46 (1961) 95

[36] Meschia, G., E. L. Makowski, D. H. Barron: Simultaneous measurements of uterine and umbilical blood flows and oxygen uptakes. Quart. J. Exp. Physiol. 52 (1966) 1

This paper is dedicated to Prof. Dr. Otto Käser on the occasion of his 60th birthday.
[37] Müller-Heubach, E., E. R. Myers, K. ADamsons: Quantitative analysis of late deceleration for the prediction of fetal oxygenation in rhesus monkey. 3. Europ. Kongr. f. Perinatale Medizin, Lausanne 1972

[38] Renou, P., W. Newman, J. Lumley, C. Wood: Fetal scalp blood changes in relation to uterine contraction. J. Obstet. Gynaec. Brit. Cwlth. 75 (1968) 629

[39] SALING, E.: Verbesserung der apparativen Herzschlagregistrierung beim Feten unter der Geburt. Fortschr. Med. 87 (1969) 777

[40] Schulz, J., K. Wernicke, D. Berg: Mütterliche Hypoxie, Nabelschnurzirkulation und die Genese von Herzschlagfrequenzdezelerationen. In: SALING, E., J. W. Dudenhausen: Perinatale Medizin Band III. 4. Deutscher Kongreß für Perinatäle Medizin Thieme, Stuttgart 1972

[41] Schulz, J., K. Wernicke, D. Berg: Die fetale Beeinflussung bei Körperarbeit der Mutter (Schaf-Experimente). 3. Europ. Kongr. f. Perinatale Medizin, Lausanne 1972

[42]. Steinsland, O. S., S. S. Passo, G. G. Nahas: Biphasic effect of hypoxia on adrenal catecholamine content. Amer. J. Physiol. 218 (1970) 995

[43] Thews, G.: Nomogramme zum Säure-Basen-Status des Blutes und zum Atemgastransport. Springer, Berlin-Heidelberg-New York 1971

[44] Walker, A., L. Maddern, E. Day, P. Renou, J. TALBOT, C. WooD: Fetal scalp tissue oxygen tension measurements in relation to maternal dermal oxygen tension and fetal heart rate. J. Obstet. Gynaec. Brit. Cwlth. 78 (1971) 1

Prof. Dr. med. D. Berg

Department of Obstetrics and Gynecology of the University of Frankfurt am Main 6000 Frankfurt 70, Ludwig-Rehn-Str. 14 Germany 